\title{
Vitamin D Deficiency in South Asian Populations: A Serious Emerging Problem
}

Vitamin D, which is described as 'the Sun Vitamin', is essential for growth and development of the body. It has been estimated that almost one billion people in the world suffer from vitamin D deficiency or insufficiency. ${ }^{1}$ Vitamin D deficiency is a global public health concern, even in tropical regions where the risk of deficiency was previously assumed to be low due to cutaneous vitamin D synthesis stimulated by exposure to sun. Poor vitamin D status, as indicated by low serum concentrations of 25 hydroxyvitamin $\mathrm{D}[25(\mathrm{OH}) \mathrm{D}]$, has been observed in South Asian populations. Unfortunately, there is high prevalence of vitamin D deficiency due to lack of proper diet, social customs and remaining confined within the four walls of primitive housing that deprives the elderly, children and female population of the benefit of the sunshine. However, limited information is available on the vitamin D status in this region.

\section{Incidence}

It is our general belief that vitamin D deficiency is prevalent only in western countries, but actual condition is reverse. It is surprising that in South Asia, $80 \%$ of the apparently healthy population is deficient in vitamin D $(<20 \mathrm{ng} / \mathrm{mL})$ and up to $40 \%$ of the population is severely deficient $(<9 \mathrm{ng} / \mathrm{mL}){ }^{2}$ Rickets, a consequence of vitamin D deficiency, is still widespread in regions, such as northern China where $42 \%$ of infants were found to suffer from this disease during the winter/spring period. ${ }^{3}$ Sachan et $\mathrm{al}^{4}$ investigated hypovitaminosis D in Lucknow, India and found that eighty four percent of pregnant women had 25(OH)D values below $22 \mathrm{ng} / \mathrm{mL}$ (the cut-off point in their research). Siddiqui and $\mathrm{Rai}^{5}$ found that in Northern Pakistan where sunlight was available in abundance, rickets was a common problem in infants and children. They attributed the hypovitaminosis $\mathrm{D}$ to malnutrition, lack of awareness and antenatal factors. Atiq et $\mathrm{al}^{6}$ investigated hypovitaminosis D in healthy breast-fed children and nursing mothers at a major teaching hospital in Karachi, Pakistan and found that 55\% of infants and $45 \%$ of mothers had very low serum
25(OH)D levels (<25 nmol/L or $10 \mathrm{ng} / \mathrm{mL})$. A preliminary study in Sylhet during the winter dry season revealed that the vitamin D status of young infants in rural Bangladesh might be poor enough to put many at risk of rickets and other potential vitamin D-related health consequences. Applying a very conservative definition of vitamin $\mathrm{D}$ deficiency $[25(\mathrm{OH}) \mathrm{D}<25 \mathrm{nmol} / \mathrm{L}]$, they estimated that about one-third of infants aged 1-6 months may be vitamin D-deficient. ${ }^{7}$ To our knowledge, this is the first report of vitamin D status in young infants in Bangladesh.

\section{Requirement of vitamin D}

The mean serum concentration of $25(\mathrm{OH}) \mathrm{D}$ of 30 $\mathrm{ng} / \mathrm{mL}$ is considered desirable for health. ${ }^{1}$ A level of $20 \mathrm{ng} / \mathrm{mL}$ is considered as minimum acceptable. ${ }^{1,8}$ The recommended daily intakes for vitamin $\mathrm{D}$ for infants, children and adults up to 50 years is $200 \mathrm{IU}$ (5 g) per day, and for adults between 50-70 years, it should be 400 IU (10 g). Several investigators have suggested that these values are insufficient, especially for pregnant females, sick adults and older adults. ${ }^{11}$ Perhaps all the adults need 800-1000 IU daily. This estimate is based on serum level of 25hydroxyvitamin D [25(OH)D] of $30 \mathrm{ng} / \mathrm{mL}$. Hypovitaminosis $\mathrm{D}$ has been defined by Thomas et al as serum levels of $25(\mathrm{OH}) \mathrm{D}$ less than $15 \mathrm{ng} / \mathrm{mL}$ (37 $\mathrm{nmol} / \mathrm{L})$. When the levels of $25(\mathrm{OH}) \mathrm{D}$ are between $8-15 \mathrm{ng} / \mathrm{mL}(20-37 \mathrm{nmol} / \mathrm{L})$, the condition is called "moderate hypovitaminosis D". When the levels of $25(\mathrm{OH}) \mathrm{D}$ become less than $8 \mathrm{ng} / \mathrm{mL}(20 \mathrm{nmol} / \mathrm{L})$, the condition is regarded as "severe hypovitaminosis D". However, investigators in general consider levels of $25(\mathrm{OH}) \mathrm{D}$ less than $20 \mathrm{ng} / \mathrm{mL}(50 \mathrm{nmol} / \mathrm{L})$ as vitamin $\mathrm{D}$ deficient states. 1,8 Vitamin D intoxication, however, occurs when serum levels of $25(\mathrm{OH}) \mathrm{D}$ are greater than $150 \mathrm{ng} / \mathrm{mL}$.

\section{Biological functions of vitamin D}

Vitamin D is actually a steroid that has a hormone like function. It facilitates calcium and phosphorus absorption through the small intestine. Vitamin D from dietary sources and from sun exposure of skin 
is stored in fat cells and is brought into circulatory system by vitamin D binding protein. Vitamin D3 (cholecalciferol) is biologically inactive and must be metabolized to $25-(\mathrm{OH}) \mathrm{D} 3$ in the liver and then to its biologically active form 1,25-dihydroxycholecalciferol [1,25-di(OH)D3] in kidney. ${ }^{9}$ In this form, vitamin $\mathrm{D}$ has been found to regulate functioning of over 200 genes, including the genes involved in cellular proliferation, apoptosis, differentiation and angiogenesis. However, 25(OH)D3 is the predominant form of vitamin $\mathrm{D}$ in plasma and the major storage form as well.

\section{Causes of vitamin D deficiency in South Asians}

Poverty and illiteracy: Poverty is one of the major reasons for most of the ills of the society including poor health. A vast majority of people are illiterate and are not aware of the importance of balanced diet. Moreover, the dietary habits are also to blame as food is often overcooked destroying most of the vitamins and micronutrients in it.

Social and religious customs: Many women stay at home which is almost closed to sunlight. Infants of these women also stay indoors and receive little or no exposure to sunlight. The old and weak persons also have no exposure to sunlight as they spend almost all of their time inside the tiny huts or houses. Most of the garment workers are engaged in duty from dawn to night, so they are not exposed to sunlight at all and they are unable to take balanced diet. The middle class urban population is now increasingly living in densely populated apartment blocks with very little natural light.

Skin pigmentation: The color of skin of South Asian populations varies from light brown to almost dark. Dark pigmentation has been found to decrease skin synthesis of vitamin D because UV light cannot reach the appropriate layer of the skin. Compared to the Caucasian population, healthy African Americans have also been found more likely to be vitamin D deficient regardless of age. ${ }^{10}$

Addictive habits: A recent study on South Asian communities in UK by Ogunkolade et al has shown that chewing betel nut (Areca catechu), an addictive habit common among South Asians, contributes to hypovitaminosis D by modulating the enzymes which regulate circulating levels of $1,25 \mathrm{di}(\mathrm{OH}) \mathrm{D} .^{11}$

\section{Impact of vitamin D deficiency}

\section{Bone mineral density}

Vitamin D deficiency is associated with secondary hyperparathyroidism with consequent ill effects on bone mineral density. Marwaha et al ${ }^{12}$ studied vitamin $\mathrm{D}$ deficiency and its effects on bone mineral density in Indian adolescents of 10-18 years of age and concluded that metabolic bone disorders secondary to vitamin D deficiency continue to be prevalent in the Indian subcontinent and are more prevalent in lower socioeconomic population. Roy et $\mathrm{al}^{13}$ have reported that in South Asian women, a decrease in serum $25(\mathrm{OH}) \mathrm{D}$ level $<15 \mathrm{ng} / \mathrm{mL}$ is associated with a progressive reduction in bone mass at the hip and wrist.

\section{Osteomalacia and rickets}

While rickets is a consequence of vitamin D deficiency in infants and children, older adults can suffer from osteomalacia due to loss of bone density causing pain and soft bones. The problem of rickets among infants and children is widespread in cooler northern areas of South Asia. ${ }^{8,9}$ Rickets remains one of the major causes of infant mortality in South Asia. ${ }^{5}$ Vitamin D deficiency in infants can often be traced to maternal nutritional status. ${ }^{7}$ Neonatal concentrations are normally $60-70 \%$ of maternal vitamin D levels. In case of maternal deficiency, the neonate's low reserves of vitamin $D$ can cause hypocalcemic symptoms in the first six months of infant's life. Finch et $\mathrm{al}^{14}$ claimed that osteomalacia was underdiagnosed in South Asians living in UK. They found that $22 \%$ of subjects in their study had varying degrees of osteomalacia.

\section{Osteoporosis}

Postmenopausal women are known to be prone to vitamin D deficiency causing an early onset of osteoporosis. The tendency to the deficiency is universal as $28.4 \%$ postmenopausal women have been found to be deficient in vitamin $\mathrm{D}[25(\mathrm{OH}) \mathrm{D}$, $<20 \mathrm{ng} / \mathrm{mL}]$ in most parts of the world. ${ }^{8}$ However, this percentage increased to $30 \%$ in a population from Southern India. 4

\section{Vitamin $D$ deficiency and other diseases}

Over 200 of human genes have receptors for vitamin $\mathrm{D}$, making vitamin $\mathrm{D}$ deficiency a contributory factor to a wide variety of other human diseases. Johnson argues "that vitamin D is important for much more than just bones; the vitamin seems to have a role in preventing colorectal and other cancers, diabetes, arthritis and even multiple sclerosis (MS)". 15

Recently, an inverse association between plasma $25(\mathrm{OH}) \mathrm{D}$ levels and risk of hypertension has been 
reported. ${ }^{16}$ Wang et al more recently, in a prospective study on 1739 participants and a mean follow-up of 5.4 years, showed vitamin D deficiency to be a risk factor for cardiovascular disease in participants with hypertension. ${ }^{17}$ Cardiomyopathy due to vitamin D deficiency in infants is a rare but potentially fatal manifestation of hypovitaminosis D. ${ }^{18}$ Richard and his associates have shown beneficial effects of vitamin $\mathrm{D}$ against aging and inflammation. ${ }^{19}$ In a study at the Alzheimer's Disease Research Center, St Louis, USA, vitamin D deficiency was found to be associated with psychiatric and neurological disorders. In another report, vitamin D deficiency was implicated in depression. ${ }^{20}$ Bottela-Carretero et al found an association between vitamin D deficiency and metabolic syndrome in obese patients. ${ }^{21}$ Patients with vitamin D deficiency had significantly lower levels of HDL-cholesterol and hypertriglyceridemia compared to patients with normal levels of vitamin D. ${ }^{21}$

\section{Recommendation}

Vitamin D deficiency is widespread in South Asian populations and is contributing to burden of disease in this region. It is suggested that the governments in South Asia should implement a mandatory vitamin D supplementation program of selected foodstuff, at least during the winter months. Vitamin D supplement and an annual intramuscular injection of a large single dose of vitamin $\mathrm{D}$ need to be considered for the special risk groups. The program needs to be reinforced through a mass awareness campaign over the electronic media informing importance of absorbing direct sunlight for at least 30 minutes a day.

The adequate vitamin $\mathrm{D}$ daily intake for South Asians also needs to be set at least twice that of the above mentioned recommended intakes for Western populations. $^{22,23}$

Pregnant women in South Asia are advised 400 IU $(10 \mathrm{~g})$ daily intake of vitamin D, but compliance to this recommendation is often very poor. ${ }^{24}$

Experience with Indian and Pakistani populations in developed countries and in India and Pakistan suggests that for conventionally dressed pregnant women receiving insufficient sunlight, a 1000 IU (25

g) daily intake of vitamin $\mathrm{D}$ is more appropriate. $^{25}$

Due to low level of compliance to recommended daily intake of vitamin $\mathrm{D}$, Lawson and Thomas ${ }^{26}$ advocate an annual intramuscular booster of 150,000 IU for children of Asian origin up to the age of five years. In order to build vitamin D store of infants, it is now a standard practice in France to give pregnant women a single large intramuscular dose of vitamin D of 100,000 to 150,000 IU during the 7 th month of pregnancy. ${ }^{10}$ A similar policy for children and pregnant women in this subcontinent needs to be considered.

\section{Conclusion}

Vitamin D deficiency has again become a major public health interest with its association with osteoporosis, osteomalacia, fractures, and more recently with prevention of cancer, diabetes, heart disease and other chronic illnesses. Regular sun exposure has decreased due to changing lifestyles. Vitamin D deficiency is especially prevalent in dark skinned children and adults living in northern latitudes, and obese children and adults. Though sunlight is God-gifted in this region, proper utilization of this resource must be done. Improving the vitamin D status worldwide would have dramatic effects on public health, and reduce healthcare costs for many chronic diseases. The most cost-effective way to remedy this deficiency is to increase food fortification with higher levels of vitamin $\mathrm{D}$ along with sensible sun exposure, and adequate vitamin D supplementation.

\section{HAM Nazmul Ahasan}

Professor

Department of Medicine

Dhaka Medical College \& Hospital, Dhaka

\section{Aparna Das}

Assistant Professor

Department of Medicine

Dhaka Medical College \& Hospital, Dhaka

Email: aparna_0191@yahoo.com 


\section{References}

1. Holick MF. Vitamin D Deficiency. N Engl J Med 2007; 357: 266-281.

2. Arya V, Bhambri R, Godbole MM, Mithal A.Vitamin D status and its relationship with bone mineral density in healthy Asian Indians. Osteoporsis Int 2004; 15(1): 5661.

3. Strand MA, Perry J, Jin M, Tracer DP, Fischer PR, Zhang $\mathrm{P}$ et al. Diagnosis of rickets and reassessment of prevalence among rural children in northern China. Pediatr Int 2007; 49: 202-209.

4. Sachan A, Gupta R, Das V, Agarwal A, Pradeep K, Awasthi PK et al. High prevalence of vitamin D deficiency among pregnant women and their newborns in northern India. Am J Clin Nutr 2005; 81: 1060-1064.

5. Siddiqui TS, Rai MI. Presentation and predisposing factors of nutritional rickets in children of Hazara division. J Ayub Med Coll 2005; 17(3): 29-32.

6. Atiq M, Suria A, Nizami SQ, Ahmed I. Vitamin D status of breast-fed Pakistani infants. Acta Paediatr 1998; 87(7): 737-740.

7. Roth DE, Shah MR, Black RE, Baqui AH. Vitamin D status of infants in northeastern rural Bangladesh: preliminary observations and a review of potential determinants. J Health Popul Nutr. 2010 October; 28(5): 458-469.

8. Lips P. Vitamin D deficiency and secondary hyperparathyroidism in the elderly: consequences for bone loss and fractures and therapeutic implications. Endocr Rev 2001; 22: 477-501.

9. Holick MF. Vitamin D - new horizons for the $21^{\text {st }}$ century. McCollum Award Lecture. Am J Clin Nutr 1994; 60: 619-623.

10. Bodnar LM, Simhan HN, Powers RW, Frank MP, Cooperstein E, Roberts JM. High prevalence of vitamin $\mathrm{D}$ deficiency in black and white pregnant women residing in the northern United States and their neonates. J Nutr 2007; 137(2): 447-452

11. Ogunkolade WB, Boucher BJ, Bustin SA, Burrin JM, Noorian K, Mannan N et al. Vitamin D metabolism in peripheral blood mononuclear cells is influenced by chewing "betel nut" (Areca catechu) in vitamin D status. J Clin Endocr Metab 2006; 91(7): 2612-2617.

12. Marwaha RK, Tandon N, Reddy D, Reddy HK, Aggarwal R, Singh R et al. Vitamin D and bone mineral density status of healthy schoolchildren in northern India. Am J Clin Nutr 2005; 82: 477-482.

13. Roy DK, Berry JL, Pye SR, Adams JE, Swarbrick CM, King Y. Vitamin D status and bone mass in UK South Asian women. Bone 2007; 40(1): 200-204.
14. Finch PJ, Ang L, Eastwood JB, Maxwell JD. Clinical and histological spectrum of osteomalacia among Asians in South London. Q J Med 1992; 83(302): 439-448.

15. Johnson R. The new vitamin D debate, eatingwell.com, http://www.healthline.com/eatingwell/eth-thenew. vitamin-d-debate

16. Forman JP, Giovannucci E, Holmes MD, BischoffFerrari HA, Tworoger SS, Willet WC et al. Plasma 25hydroxy vitamin D levels and risk of incident hypertension. Hypertension 2007; 49: 1063-1069.

17. Wang TJ, Pencina MJ, Booth SL, Jacqwues PF, Ingelsson $\mathrm{E}$, Lanier $\mathrm{K}$ et al. Vitamin D deficiency and risk of cardiovascular disease. Circulation 2008; 29(117): 503-511.

18. Maiya S, Allgrove J, Mok Q. Vitamin D deficiency and mortality and serious morbidity in infancy: time for action. Arch Dis Child 2006; 91: A71.

19. Richards JB, Valdes AM. Higher serum vitamin D concentrations are associated with longer leukocyte telomere length in women. Am J Clin Nutr 2007; 85: $1420-1425$.

20. Berk M, Sanders KM, Pasco JA, Jacka FN, Williams LJ, Hayles AL et al. Vitamin D deficiency may play a role in depression. Med Hypotheses 2007; 69(6): 1316-1319.

21. Botella-Carretero JI, Alvarez-Blasco F, Villafruela JJ, Balsa JA, Vá zquez C, Escobar-Morreale HF. Vitamin $\mathrm{D}$ deficiency is associated with the metabolic syndrome in morbid obesity. Clin Nutr 2007; 26: 573-580.

22. Vitamins and minerals requirements in human nutrition. $2^{\text {nd }}$ edn. World Health Organization and Food and Agriculture Organization of the United Nations 2004: $45-58$.

23. Standing committee on the scientific evaluation of dietary reference intakes, Institute of Medicine. Dietary reference intakes: calcium, phosphorus, magnesium, vitamin D and fluoride. Washington, D.C. National Academy Press, 1997.

24. Brunvald L, Henriken C, Haug E. Vitamin D deficiency among pregnant women in Pakistan. How best to prevent it? Tidsskr Nor Laegeforen 1996; 116: 15851587.

25. Glerup H, Mikkelsen K, Poulsen L, Hass E, Overbeck $\mathrm{S}$, Thomsen $\mathrm{J}$ et al. Commonly recommended daily intake of vitamin D is not sufficient if sunlight exposure is limited. J Intern Med 2000; 247: 260-268.

26. Lawson M, Thomas M. Vitamin D concentrations in Asian children aged two years living in England: population survey. BMJ 1999; 318-328. 